\title{
ßututland 羽apers.
}




\section{Zintlatid 非apers.}

\section{ORIGINAL DOCUMENTS}

ILLUSTRATIVE OF THE

COURTS AND TIMES OF HENRY VII. AND HENRY VIII.

SELECTED FROM THE PRIVATE ARCHIVES OF

HIS GRACE THE DUKE OF RUTLAND, \&c. \&c. \&c.

BY

WILLIAM JERDAN, F.S.A. M.R.S.L.,

CORResponding member of the Real academia de la historia of Spain, \&c. \&c. \&c.

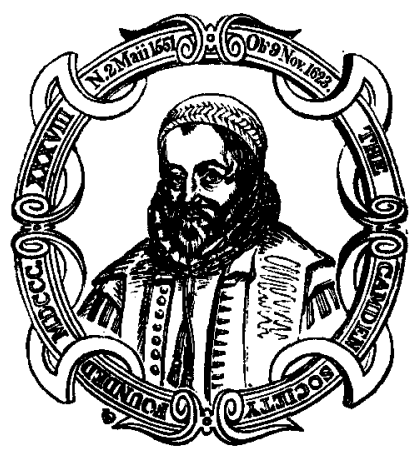

L O N D O N :

PRINTED FOR THE CAMDEN SOCIETY,

BY JOHN BOWYER NICHOLS AND SON, PARLIAMENT STREET.

M.DCCC.XLII. 


\title{
COUNCIL
}

\author{
OF \\ THE CAMDEN SOCIETY, \\ FOR THE YEAR 1842-3.
}

\section{President,}

THE RIGHT HON. LORD FRANCIS EGERTON, M.P.

THOMAS AMYOT, ESQ. F.R.S. Treas. S.A. Director.

THE RIGHT HON. LORD BRAYBROOKE, F.S.A.

JOHN BRUCE, ESQ. F.S.A. Treasurer.

JOHN PAYNE COLLIER, ESQ. F.S.A.

C. PURTON COOPER, ESQ. Q.C., D.C.L., F.R.S., F.S.A.

T. CROFTON CROKER, ESQ. F.S.A., M.R.I.A.

SIR HENRY ELLIS, K.H., F.R.S., Sec. S.A.

JAMES ORCHARD HALLIWELL, ESQ. F.R.S., F.S.A.

THE REV. JOSEPH HUNTER, F.S.A.

SIR FREDERICK MADDEN, K.H., F.R.S., F.S.A.

JOHN HERMAN MERIVALE, ESQ. F.S.A.

THE REV. LANCELOT SHARPE, M.A., F.S.A.

THOMAS STAPLETON, ESQ. F.S.A.

WILLIAM J. THOMS, ESQ. F.S.A. Secretary.

THOMAS WRIGHT, ESQ. M.A., F.S.A. 